Original Paper

\title{
Edukasi Perilaku Hidup Bersih dan Sehat (PHBS) dalam Pencegahan COVID-19 Kepada Anak-Anak di Panti Asuhan
}

\author{
Alif Yanuar Zukmadini1 ${ }^{*}$, Bhakti Karyadi1 ${ }^{1}$ Kasrina $^{1}$ \\ ${ }^{1}$ Program Studi Pendidikan Biologi, Fakultas Keguruan dan Ilmu Pendidikan, Universitas Bengkulu, \\ Bengkulu, Indonesia
}

DOI: 10.29303 /ipmpi.v3i1.440

Sitasi: Zukmadini, A.Y., Karyadi, B., \& Kasrina, K. (2020). Edukasi Perilaku Hidup Bersih dan Sehat (PHBS) dalam Pencegahan COVID-19 Kepada Anak-Anak di Panti Asuhan. Jurnal Pengabdian Magister Pendidikan IPA, 3(1). doi: https:// doi.org/10.29303/jpmpi.v3i1.440

*Corresponding Author: Alif Yanuar Zukmadini, Program Studi Pendidikan Biologi, Fakultas Keguruan dan Ilmu Pendidikan, Universitas Bengkulu, Bengkulu, Indonesia

Email:

ayzukmadini@unib.ac.id

\begin{abstract}
Abstrak: COVID-19 menyebabkan penyakit yang menyerang sistem pernapasan pada manusia. Virus ini telah menginfeksi jutaan orang sehingga menyebabkan angka kematian yang tinggi bagi penderitannya di seluruh dunia. Anak-anak termasuk juga anak-anak yatim piatu yang tinggal di panti asuhan sangat rentan terhadap penularan COVID-19. Kegiatan ini bertujuan untuk memberikan edukasi dan pendampingan kepada anak-anak panti asuhan Kasih Sayang Kota Bengkulu untuk menerapkan pola perilaku hidup bersih dan sehat (PHBS) agar terhindar dari penularan COVID-19. Kegiatan ini juga diikuti dengan pemberian sembako kepada anak-agar panti asuhan agar dapat memenuhi kebutuhannya selama pandemi COVID-19. Edukasi dilakukan menggunakan metode kaji tindak dengan pendekatan partisipatif. Materi edukasi yang diberikan kepada anak-anak panti asuhan diantaranya pengenalan COVID-19 dan gejalanya, cara mencuci tangan yang baik dan benar, cara menerapkan etika batuk, cara physical distancing, serta cara menerapkan pola hidup bersih dan sehat. Kegiatan edukasi dilakukan dengan memberikan penyuluhan terhadap PHBS dalam pencegahan COVID-19 dengan menggunakan metode ceramah, diskusi, tanya jawab, dan demontsrasi. Penyampaian materi juga dilakukan dengan menggunakan media pembelajaran berupa poster. Evaluasi dilakukan dengan menggunakan lembar angket untuk mengetahui pengetahuan peserta sebelum dan setelah diberikan edukasi. Hasil kegiatan menujukkan bahwa edukasi yang diberikan oleh fasilitator dapat meningkatkan pengetahuan anakanak panti asuhan terhadap perilaku hidup bersih dan sehat dalam pencegahan COVID-19. Hal ini dapat dilihat dari persentase pengetahuan peserta sebelum diberikan edukasi yaitu sebesar $74,48 \%$ yang kemudian meningkat menjadi $86,49 \%$ setelah diberikan edukasi.
\end{abstract}

Kata Kunci: PHBS; COVID-19; Anak Panti Asuhan; Edukasi; Sembako.

\section{Pendahuluan}

Corona Virus Disease 2019 atau COVID-19 adalah jenis penyakit baru yang disebabkan oleh infeksi Virus Severe Acute Respiratory Syndrome Coronavirus 2 (SARS-
COV-2) atau yang dikenal dengan novel coronavirus (2019-nCoV) (Singhal, 2020). Dari awal kemunculannya di akhir tahun 2019 hingga 20 Mei 2020, penyakit ini telah menginfeksi 4.789.205 orang dan 
menyebabkan kematian terhadap 318.789 orang di seluruh dunia. (WHO, 2020).

Penyakit ini ditularkan melalui droplet (percikan) pada saat berbicara, batuk, dan bersin dari orang yang terinfeksi virus Corona. Selain itu penyakit ini juga dapat ditularkan melalui kontak fisik (sentuhan atau jabat tangan) dengan penderita serta menyentuh wajah, mulut, dan hidung oleh tangan yang terpapar virus Corona (Singhal, 2020).

Gejala klinis yang muncul akibat terinfeksi virus ini seperti gejala flu biasa (demam, batuk, pilek, nyeri tenggorokan, nyeri otot, nyeri kepala) hingga komplikasi berat (diare dan pneumonia) hingga menyebabkan kematian (Huang dkk, 2020: Chen 2020. Anak-anak termasuk ke dalam kelompok usia yang sangat rentan terhadap penularan COVID-19 dari lingkungan sekitarnya. Sebagian anak-anak yang terinfeksi COVID-19 seringkali tidak menunjukkan gejala infeksi. (Zimmermann dan Curtis, 2020).

Menurut UU Nomor 23 Tahun 2002 tentang perlindungan anak, disebutkan bahwa anak merupakan amanah dan karunia Tuhan YME yang dalam dirinya melekat harkat dan martabat sebagai manusia seutuhnya. Oleh karena itu setiap anak berhak atas keberlangsungan hidup, tumbuh dan berkembang serta berhak atas perlindungan dari kekerasan dan diskriminasi. Anak yatim piatu adalah mereka yang sudah tidak memiliki orang tua lagi dan keluarga yang memeliharanya. Mereka termasuk anak yang menderita, lemah dan menjadi korban kehilangan kasih sayang orangtua baik di bidang pendidikan ataupun di bidang yang lain (Syaitut, 1991).

Kesulitan hidup seseorang dapat terjadi apabila kebutuhan pokoknya tidak dapat dipenuhi (Rahmat, 1999). Termasuk dalam hal ini adalah anak yatim piatu yang tinggal di panti asuhan. Di sana mereka memiliki kesulitan dalam hal pemenuhan kebutuhan pokok serta ketiadaan kasih sayang dari orang tua. Panti asuhan merupakan tempat atau kediaman untuk merawat anakanak yatim piatu (Depdikbud, 1999).
Dalam aktivitasnya sehari-hari, anakanak panti asuhan menghabiskan waktu mereka untuk sekolah, belajar, mengaji, dan berbagai kegiatan positif lainnya. Hampir sebagian besar dari mereka sudah terbiasa untuk melakukan aktivitas secara mandiri. Hal ini menjadi kesedihan tersendiri bagi mereka karena harus menjalani hari-hari tanpa orang tua kandung, hanya orang tua asuh (pengurus panti) yang mendampingi mereka.

Dari hasil observasi yang dilakukan terhadap anak-anak di Panti Asuhan Kasih Sayang Kota Bengkulu, terdapat 45 orang anak-anak yang diasuh dan tinggal di panti ini, anak-anak tersebut berasal dari kelompok yatim/piatu/yatim piatu dan anak-anak dari keluarga tidak mampu. Hasil wawancara dengan pengasuh panti asuhan diperoleh informasi bahwa dalam masa pandemi COVID-19 saat ini, anak-anak sangat membutuhkan pendampingan dalam menerapkan perilaku hidup bersih dan sehat selama masa pandemi COVID-19 serta pemenuhan kebutuhan hidup sehari-hari.

Anak-anak panti asuhan dalam kondisi saat ini seyogyanya mendapatkan perhatian khusus tentang cara pencegahan dan penularan COVID-19, serta mendapatkan jaminan terpenuhinya kebutuhan sehari-hari mereka di panti asuhan. Hanya saja keterbatasan sumber informasi baik dari orang tua, pengasuh, ataupun media lainnya membuat mereka masih perlu mendapatkan bimbingan untuk menerapkan perilaku hidup bersih dan sehat (PHBS) yang menjadi protokol dalam pencegahan COVID-19. Pembatasan sosial (social distancing) yang terjadi juga berdampak terhadap pemenuhan kebutuhan pokok mereka. Sebagaimana diketahui bahwa panti asuhan menggantungkan pemenuhan kebutuhan pokok mereka dari sumbangan dan bantuan orang lain.

Untuk meminimalisir penularan COVID-19 serta menjamin kebutuhan hidup anak-anak di panti asuhan, maka perlu dilakukan edukasi untuk mengajarkan bagaimana perilaku hidup bersih dan sehat 
(PHBS) yang menjadi protokol pengangan COVID-19 serta pemberian bantuan Sembako Menurut Kepmenperindag 115/1998, Sembilan Bahan Pokok atau sering disingkat Sembako adalah sembilan jenis kebutuhan pokok masyarakat yang meliputi beras, gula pasir, minyak goreng dan mentega, daging sapi dan ayam, telur ayam, susu, jagung, minyak tanah, dan garam beryodium. Sedangkan PHBS (Perilaku Hidup Bersih dan Sehat) merupakan sekumpulan perilaku yang dipraktikkan atas dasar kesadaran sebagai hasil pembelajaran yang menjadikan seseorang, keluarga, kelompok atau masyarakat agar mampu menolong dirinya sendiri (mandiri) di bidang kesehatan dan berperan aktif dalam mewujudkan kesehatan masyarakat (Peraturan Menteri Kesehatan Republik Indonesia Nomor 2269).

Menurut Razi dkk (2020), perilaku hidup bersih dan sehat (PHBS) untuk pencegahan virus COVID-19 dapat berupa cara mencuci tangan yang baik dan benar, cara menerapkan etika batuk, cara melakukan Physical Distancing (menjaga jarak fisik), dan cara menjaga kebersihan diri. Pemberian edukasi mengenai PHBS ini dapat dilakukan dengan penyuluhan atau dengan menggunakan media berupa poster. Menurut Arsyad (2013), salah satu bentuk media pembelajaran cetak yang dapat dengan mudah digunakan untuk menyampaikan informasi kepada pembaca adalah poster. Kegiatan edukasi PHBS serta pembagian sembako yang dilakukan di panti asuhan kasih sayang diharapkan dapat memberikan pemenuhan kebutuhan pokok, serta pengetahuan dan keterampilan dalam menerapkan pola perilaku hidup bersih secara mandiri agar mereka dapat terhindar dari penularan COVID-19t.

\section{Metode Pelaksanaan}

Metode yang digunakan dalam kegiatan ini adalah metode kaji tindak (Action Research) dengan pendekatan program tindak partisipatif (Partisipatory Action Program) yang melibatkan kelompok masyarakat sasaran yaitu 45 orang anak-anak yatim piatu. Kegiatan pengabdian dilaksanakan pada tanggal 22 Mei 2020 di Panti Asuhan Kasih Sayang, Kelurahan Bentiring, Kecamatan Muara Bangkahulu, Kota/Provinsi Bengkulu.

Tahapan kegiatan ini terdiri dari tahap persiapan, pelaksanaan, dan evaluasi. Tahap persiapan meliputi identifikasi masalah yang dilakukan dengan teknik wawancara dan observasi ke panti asuhan, penyiapan materi oleh fasilitator, dan persiapan media edukasi berupa poster bergambar. Tahapan pelaksanaan meliputi penyampaian materi edukasi tentang PHBS dan pembagian sembako kepada anak-anak yatim piatu. Penyampaian materi dilakukan dengan memberikan penyuluhan, pendampingan, serta bimbingan mengenai perilaku hidup bersih dan sehat (PHBS) dalam pencegahan COVID-19. Metode yang digunakan dalam menyampaikan materi adalah ceramah, tanya jawab, diskusi, dan demonstrasi.

Tahapan evaluasi meliputi penilaian pengetahuan peserta mengenai PHBS dalam pencegahan COVID-19. Tahap evaluasi (penilaian) dilakukan sebelum dan sesudah peserta mendapatkan edukasi mengenai PHBS. Kegiatan evaluasi bertujuan untuk mengetahui pengaruh kegiatan edukasi terhadap pengetahuan peserta mengenai PHBS dalam pencegahan COVID-19. Metode evaluasi yang digunakan adalah menggunakan angket (kuisioner) dan observasi. angket berisi sejumlah pertanyaan tentang pengetahuan peserta mengenai PHBS dalam pencegahan COVID-19.

\section{Hasil dan Pembahasan}

Pelaksanaan kegiatan edukasi perilaku hidup bersih dan sehat (PHBS) dalam pencegahan COVID-19 di Panti Asuhan Kasih Sayang, Kota Bengkulu telah terlaksana dengan baik mulai dari tahap persiapan hingga tahap evaluasi.

\section{Edukasi Mengenai PHBS dalam Pencegahan COVID-19}


Kegiatan ini dilakukan dengan memberikan pengetahuan kepada anak yatim piatu mengenai COVID-19 dan gejalanya, serta memberikan pendampingan dan bimbingan dalam menerapkan perilaku hidup bersih dan sehat agar terhindar dari COVID-19. Perilaku hidup bersih dan sehat (PHBS) yang diajarkan kepada anak-anak agar mereka terhindar dari COVID-19 adalah cara mencuci tangan yang baik dan benar, cara menerapkan etika batuk, cara melakukan jaga jarak fisik (Physical Distancing), dan cara menjaga kebersihan diri. Kegiatan edukasi PHBS dalam pencegahan COVID-19 dapat dilihat pada Gambar 1.

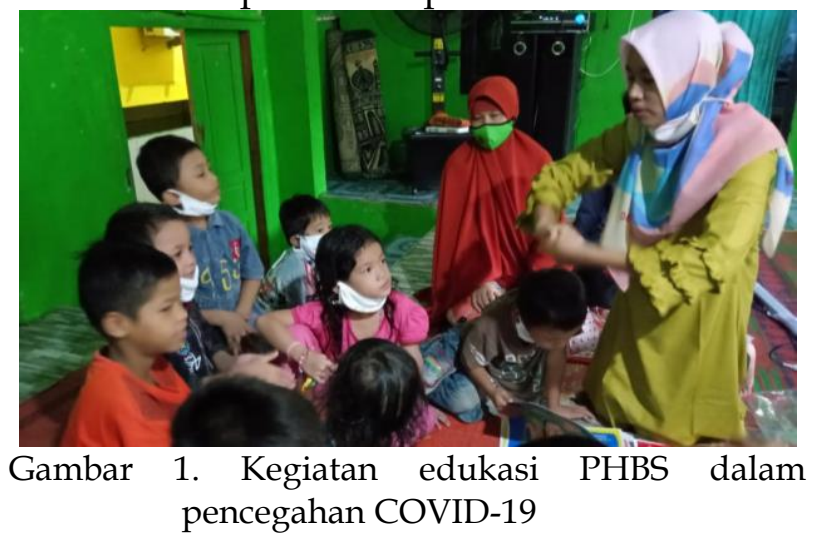

Kegiatan diikuti dengan antusias oleh peserta, hal ini dilihat dari keaktifan peserta dalam mengikuti kegiatan dari awal hingga akhir, keberanian peserta dalam menjawab pertanyaan yang diberikan oleh fasilitator, serta motivasi yang tinggi untuk belajar. Dalam kegiatan ini, tim pengabdian yang terdiri dari 3 orang dosen sebagai fasilitator dan 3 orang mahasiswa dari Program Studi Pendidikan Biologi sebagai pendamping.

Adapun media yang digunakan adalah poster bergambar. Media poster bergambar yang dipilih adalah poster berwarna yang memuat gambar/ilustrasi mengenai PHBS dalam pencegahan COVID-19. Poster-poster tersebut selanjutnya ditempel di beberapa bagian ruangan panti asuhan agar anak-anak selalu ingat dalam menerapkan PHBS sehingga terhindar dari penularan COVID-19. Menurut Hasnun (2006), poster merupakan salah satu media berisi gambar atau tulisan di atas kertas atau kain yang berisi pemberitahuan. Media poster bergambar dipilih karena informasi yang ada di dalamnya disajikan dengan menarik dan mudah diingat bagi mereka yang melihatnya. Hal ini sesuai dengan pendapat Sudjana dan Rivai (2019) yang menyatakan bahwa poster merupakan media kombinasi visual dari rancangan yang kuat, berwarna dan memiliki pesan dengan maksud untuk menangkap perhatian orang yang lewat, meskipun gagasan yang disampaikan membutuhkan waktu yang tidak singkat untuk tertanam dalam pikiran pembacanya. Edukasi menggunakan poster dapat dilihat pada Gambar 2 dan Gambar 3.

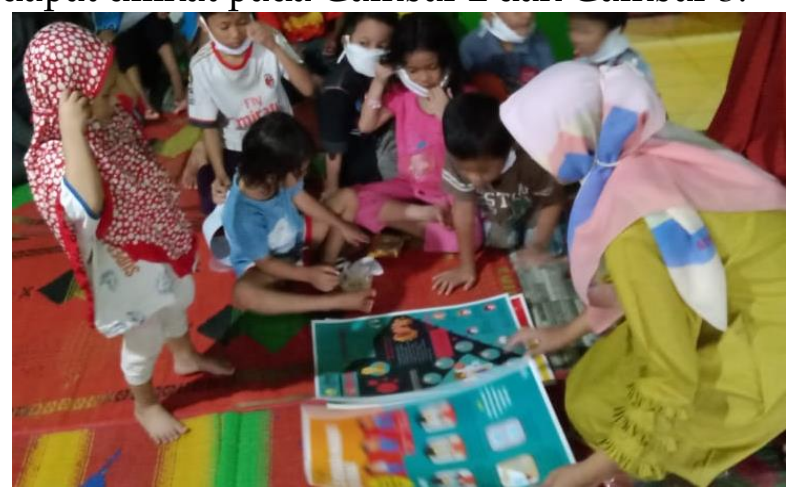

Gambar 2. Penggunaan Poster bergambar dalam menyampaikan Materi

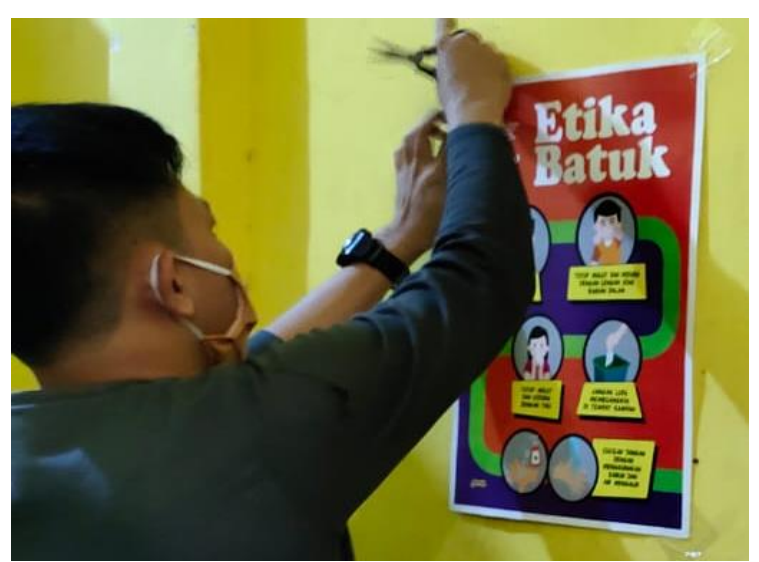

Gambar 3. Penempelan Poster Mengenai Protokol Pencegahan COVID-19 di Ruangan Panti Asuhan

Selain memberikan edukasi mengenai pengetahuan, peserta juga diajarkan untuk mempraktekkan secara langsung pengetahuan PHBS yang diperolehnya. Pada tahap ini, fasilitator mendemonstrasikan bentuk-bentuk PHBS dalam pencegahan COVID-19, kemudian anak-anak yatim piatu diarahkan 
untuk melakukan praktek secara langsung apa yang telah didemonstrasikan oleh fasilitator. Dalam hal ini fasilitator berperan sebagai pendamping anak-anak yatim piatu dalam memberdayakan pengetahuan dan keterampilan mereka terhadap perilaku hidup bersih dan sehat (PHBS) untuk pencegahan COVID-19. Menurut Agustin dan Supriyadi (2017) fasilitator berperan dalam memberikan pengetahuan yang relevan kepada kelompok pemberdayaan masyarakat, sehingga kelompok sasaran mampu mencapai tujuan yang diinginkan.

\section{Pembagian Sembako}

Anak-anak yatim piatu yang tinggal di Panti asuhan merupakan salah satu kelompok masyarakat yang terkena dampak pandemi COVID-19. Oleh sebab itu, untuk mengurangi beban mereka maka kegiatan edukasi ini juga diikuti dengan pembagian sembako untuk memenuhi kebutuhan sehari-hari. Jenis sembako yang dibagikan diantaranya beras, telur, minyak goreng, gula, susu, sarden, mie instan, dan sebagainya. Pembagian sembako kepada pihak pengelola Panti Asuhan Kasih Sayang Kota Bengkulu dapat dilihat pada Gambar 4.

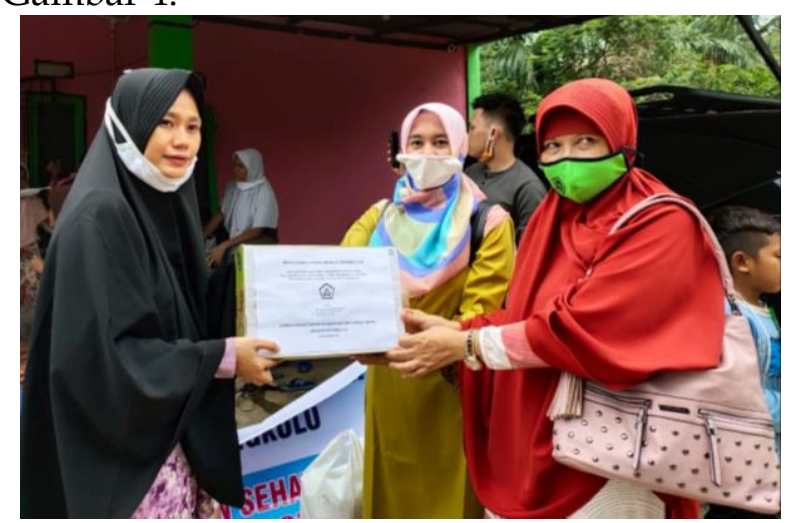

Gambar 4. Pembagian Sembako secara Simbolis Kepada Pengelola Panti Asuhan

\section{Evaluasi Kegiatan}

Evaluasi kegiatan bertujuan untuk mengetahui perubahan pengetahuan peserta mengenai PHBS dalam pencegahan COVID-19 antara sebelum dan sesudah diberikan materi. Sebelum peserta diberikan materi pengenai PHBS dalam pencegahan COVID-19, peserta diminta mengisi lembar angket yang berisi sejumlah daftar pertanyaan mengenai PHBS. Setelah diberikan angket di awal, fasilitator menyampaikan materi dan mendemonstrasikan contoh perilaku hidup sehat. Kemudian, peserta diminta kembali mengisi angket di akhir kegiatan. Hasil evaluasi pengetahuan siswa mengenai PHBS dalam pencegahan COVID-19 sebelum dan sesudah diberikan materi dapat dilihat pada Tabel 1.

Tabel 1. Pengetahuan Siswa Mengenai PHBS dalam Pencegahan COVID-19

\begin{tabular}{lll}
\hline \multirow{2}{*}{ Materi } & \multicolumn{2}{l}{ Skor Pengetahuan Peserta } \\
\cline { 2 - 3 } & $\begin{array}{l}\text { Sebelum } \\
\text { edukasi }\end{array}$ & $\begin{array}{l}\text { Setelah } \\
\text { Edukasi }\end{array}$ \\
\hline $\begin{array}{l}\text { COVID-19 dan } \\
\text { Gejala penyakitnya }\end{array}$ & 69 & 82,28 \\
\hline $\begin{array}{l}\text { Cara mencuci } \\
\text { tangan }\end{array}$ & 79 & 87,5 \\
$\begin{array}{l}\text { yang baik dan } \\
\text { benar }\end{array}$ & \\
$\begin{array}{l}\text { Cara menerapkan } \\
\text { Etika Batuk } \\
\begin{array}{l}\text { Cara menerapkan } \\
\text { Physical Distancing }\end{array}\end{array}$ & 73,8 & 87,2 \\
$\begin{array}{l}\text { Cara menjaga } \\
\text { kebersihan diri }\end{array}$ & 76,6 & 87,5 \\
\hline
\end{tabular}

Berdasarkan Tabel 1 diketahui bahwa terdapat perbedaan skor pengetahuan awal dan pengetahuan akhir peserta mengenai PHBS dalam pencegahan COVID-19 pada saat sebelum dan sesudah diberikan edukasi. Dari hasil analisis persentase, terdapat peningkatan persentase pengetahuan siswa secara keseluruhan dari semua aspek edukasi PHBS yang disampaikan oleh fasilitator. Hal ini menunjukkan bahwa edukasi PHBS yang diberikan dapat meningkatkan pengetahuan anak-anak panti asuhan terhadap pencegahan COVID-19. Hasil kegiatan ini sesuai dengan hasil kegiatan pengabdian yang dilakukan oleh Rahmadeni dkk (2019), bahwasanya kegiatan penyuluhan PHBS dapat meningkatkan pengetahuan anak-anak di panti asuhan. Persentase kenaikan pengetahuan siswa mengenai PHBS dalam 
pencegahan COVID-19 sebelum dan sesudah kegiatan dapat dilihat pada Gambar 5.

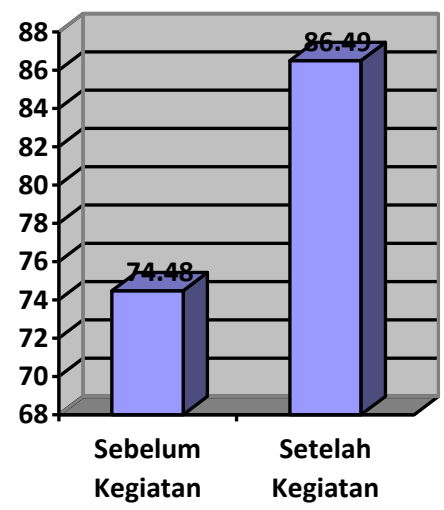

$\square$ Persentase

Pengetahuan

Gambar 5. Perbandingan Persentase Pengetahuan Peserta Mengenai PHBS dalam Pencegahan COVID-19 Sebelum dan Sesudah Kegiatan

Berdasarkan Gambar 5, diperoleh data bahwa persentase pengetahuan peserta mengenai PHBS dalam pencegahan Covid 19 sebelum dilaksanakan kegiatan ini adalah $74,48 \%$. Setelah diberikan materi melalui kegiatan ceramah, tanya jawab, diskusi, dan demonstrasi, terdapat kenaikan persentase pengetahuan sebesar $12,01 \%$ menjadi $86,48 \%$. Jika dilihat dari kenaikan persentase yang diperoleh, pada dasarnya, anak-anak yatim piatu sudah memperoleh informasi awal yang cukup untuk membekali diri mereka agar terhindar dari COVID-19. Adanya kegiatan edukasi yang diberikan oleh fasilitator menjadikan pengetahuan yang mereka miliki menjadi semakin meningkat. Meningkatnya pengetahuan peserta dapat dipengaruhi oleh beberapa faktor. Menurut Mubarak (2007) faktor yang mempengaruhi pengetahuan seseorang diantaranya informasi, pendidikan, pekerjaan, umur, minat, pengalaman, dan budaya.

Sebelum dilaksanakan kegiatan edukasi, perilaku dan pengetahuan anak-anak agar terhindar dari COVID-19 diperoleh dari beberapa sumber seperti berita di televisi, selebaran, informasi dari orang lain, dan sosial media. Hal tersebut menjadi sumber informasi sekaligus sumber belajar bagi anak-anak yatim piatu untuk mempelajari perilaku hidup bersih dan sehat agar terhindar dari penularan COVID-19. Menurut Sanjaya (2010) sumber belajar adalah segala sesuatu yang ada di sekitar lingkungan belajar peserta didik, sehingga dapat digunakan untuk membantu mengoptimalkan pengetahuan siswa dalam mencapai tujuan yang diinginkan. Persentase pengetahuan peserta untuk setiap aspek PHBS dalam pencegahan COVID-19 setelah diberikan edukasi dapat dilihat pada Gambar 6.

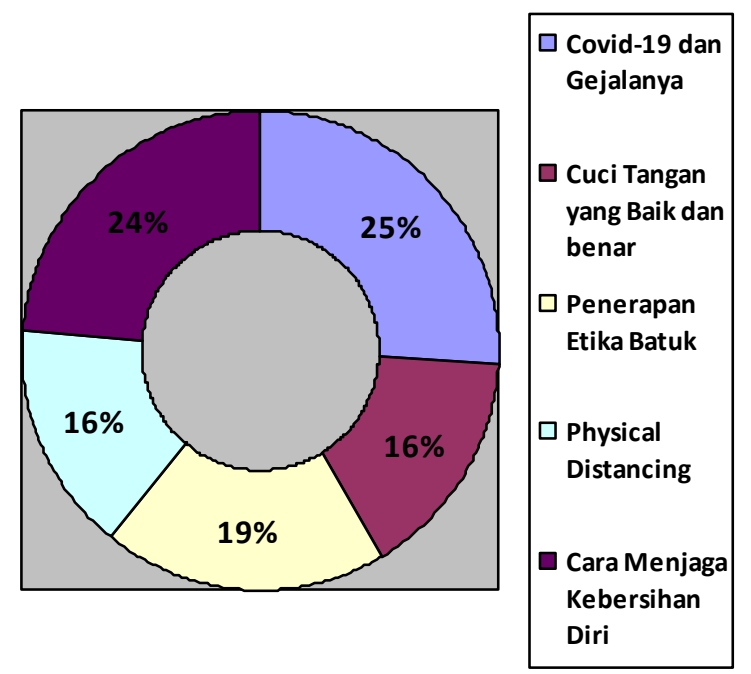

Gambar 6. Persentase Pengetahuan Anak Yatim Piatu terhadap Setiap aspek PHBS dalam Pencegahan COVID-19

Berdasarkan Gambar 6 diketahui bahwa, persentase pengetahuan anak-anak panti asuhan terhadap PHBS dalam pencegahan COVID-19 yang paling tinggi terdapat pada aspek COVID-19 dan Gejalanya $(25 \%)$, sedangkan persentase paling rendah terdapat pada aspek Penerapan Physical distancing (16\%) dan Etika Batuk (16\%). Tingginya pengetahuan peserta terhadap informasi COVID-19 dan gejalanya menunjukkan bahwa informasi tersebut banyak tersebar dan cepat diperoleh dari lingkungan sekitar tempat tinggal mereka. Sedangkan rendahnya pengetahuan peserta dalam menerapkan etika batuk dan physical distancing dikarenakan terbatasnya sumber informasi yang menjelaskan bagaimana cara yang benar ketika batuk dan ketika menjaga jarak fisik dengan orang lain. Rendahnya 
pengetahuan dari kedua aspek tersebut ternyata mempengaruhi sikap dan perilaku anak-anak dalam kesehariannya, hal ini dapat dilihat pada saat pelaksanaan kegiatan edukasi di panti asuhan, masih banyak anakanak yang tidak dapat menjaga jarak fisik dengan orang lain. Temuan tersebut sejalan dengan pendapat Papalia dkk (2008) dan Notoatmodjo (2007) yang menyatakan bahwa pengetahuan dan perilaku seseorang dipengaruhi oleh lingkungan dan informasi yang ada.

Edukasi PHBS yang diberikan merupakan bentuk kegiatan yang tidak hanya sekedar memberikan pengetahuan semata, melainkan juga memberikan keterampilan melalui pembimbingan agar anak-anak panti asuhan dapat menerapkannya secara mandiri dalam kehidupan sehari-hari. Kegiatan ini merupakan bentuk kegiatan pendidikan yang secara informal diharapkan dapat mempengaruhi pengetahuan, keterampilan dan sikap/perilaku peserta. Hal ini sesuai dengan pendapat Hamalik (2010) yang menyatakan bahwa pendidikan merupakan suatu usaha yang bertujuan untuk mempengaruhi peserta didik dalam menyesuaikan diri dengan lingkungannya, sehingga menimbulkan perubahan dalam dirinya agar dapat berfungsi secara kuat dalam kehidupan masyarakat.

Secara berkelanjutan edukasi ini diharapkan dapat menjadi perilaku hidup yang dapat diterapkan secara disiplin oleh anak-anak panti asuhan agar mereka terhindar dari COVID-19. Menurut Kurniawan (2017), kegiatan edukasi yang diberikan kepada anakanak panti asuhan dapat menjadi landasan dalam melakukan perilaku hidup bersih dan sehat (PHBS) untuk mencapai derajat kesehatan yang baik. Upaya memberikan pengetahuan (edukasi) tentang perilaku hidup bersih dan sehat kepada anak-anak yatim piatu dapat menjadi salah satu upaya untuk meminimalisir faktor resiko penularan COVID-19 kepada anak-anak. Dalam jangka panjang pengetahuan yang telah mereka peroleh dapat berkembang menjadi sebuah perilaku kemandirian dan menjadi suatu habituasi (kebiasaan) untuk diterapkan dalam kehidupan mereka sehari-hari. Pola edukasi perilaku hidup bersih dan sehat yang diharapkan dapat berkembang dalam diri anak-anak panti asuhan agar terhindar dari penularan COVID-19 digambarkan pada Gambar 7.

\section{EDUKASI PHBS UNTUK MELINDUNGI DIRI DARI COVID-19 BAGI \\ ANAK-ANAK PANTI ASUHAN}

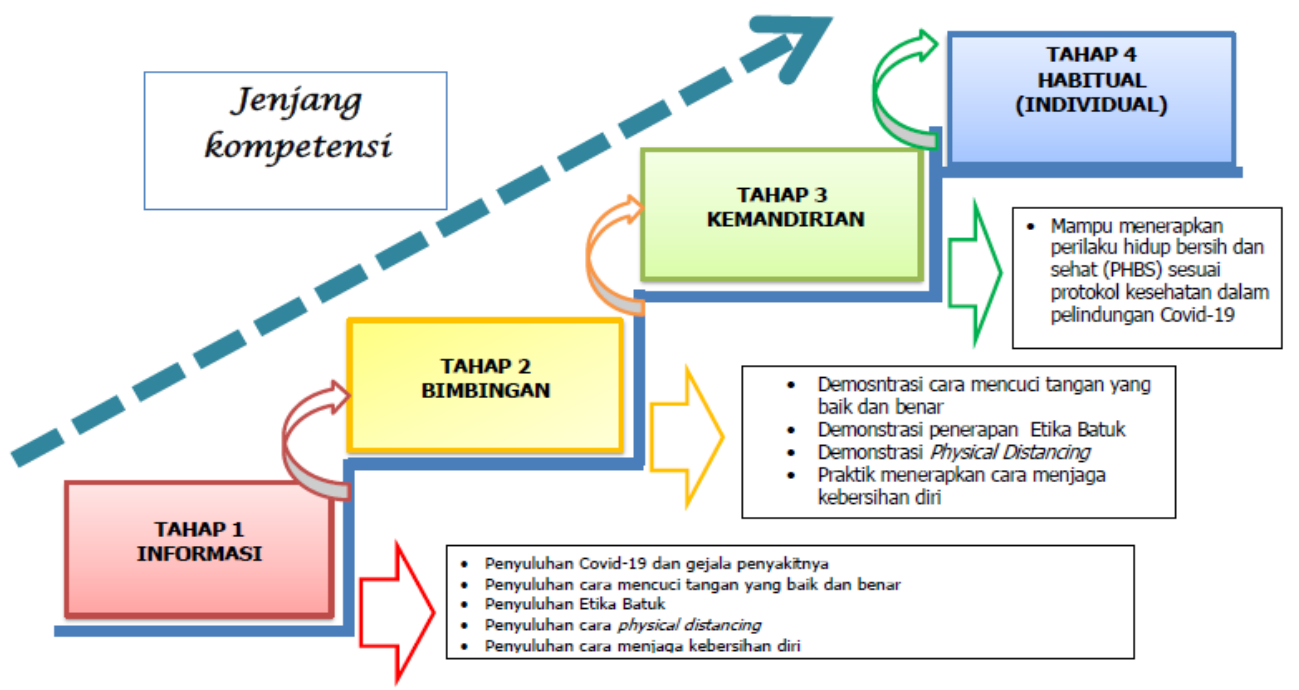

Gambar 7 . Pola Kegiatan Edukasi PHBS untuk melindungi diri dari COVID-19 bagi Anak-Anak Panti Asuhan 
Peningkatan pengetahuan peserta mengenai PHBS dalam pencegahan COVID-19 diharapkan dapat diikuti oleh peningkatan sikap dan perilaku anak untuk menerapkannya secara mandiri. Oleh sebab itu kemandirian yang telah terdapat dalam diri mereka perlu didukung oleh keadaan lingkungan di sekitarnya. Menurut Basri (1995), pola asuh, kondisi sosial budaya, serta kondisi sosial ekonomi merupakan faktor eksternal yang mempengaruhi pembentukan kemandirian anak

\section{Kesimpulan}

Kesimpulan yang diperoleh dari pelaksanaan kegiatan pengabdian masyarakat ini yaitu, 1) Edukasi mengenai Perilaku Hidup Bersih dan Sehat (PHBS) dalam Pencegahan COVID-19 dapat meningkatkan pengetahuan anak-anak di Panti Asuhan Kasih Sayang Kota Bengkulu. Hal ini terlihat dari kenaikan persentase pengetahuan peserta sebelum kegiatan yaitu sebesar $74,48 \%$ kemudian meningkat menjadi 86,48 \% setelah kegiatan; 2) Materi Edukasi PHBS dalam pencegahan COVID-19 yang diberikan kepada anak-anak Panti Asuhan Kasih Sayang Kota Bengkulu yaitu Pengenalan COVID-19 dan gejalanya, cara mencuci tangan yang baik dan benar, cara menerapkan etika batuk, cara menerapkan physical distancing, serta cara menjaga kebersihan diri; 3) Kegiatan edukasi PHBS dalam pencegahan COVID-19 diikuti dengan kegiatan pembagian sembako kepada anakanak Panti Asuhan Kasih Sayang Kota Bengkulu sebagai upaya memberikan bantuan kepada mereka yang terkena dampak pandemi COVID-19.

\section{Ucapan Terimakasih}

Penulis mengucapkan terima kasih kepada Lembaga Penelitian dan Pengabdian Masyarakat (LPPM) Universitas Bengkulu yang telah memberikan dukungan finansial dalam pelaksananaan kegiatan pengabdian ini melalui skema Pembinaan Universitas
Bengkulu dengan Nomor Kontrak 1511/UN30.15/AM/2020.

\section{Daftar Pustaka}

Agustin, W. A., dan Supriyadi, S. N. (2007). Peran Fasilitator Dalam Pemberdayaan Masyarakat Pada Program Penataan Lingkungan Permukiman Berbasis Komunitas. Jurnal Sosiologi DILEMA. 32 (1). 69-78.

Arsyad, A. (2013). Media Pembelajaran, edisi revisi. PT Raja Grafindo Persada: Jakarta.

Basri, H. (1995). Remaja Berkualitas: Problematika Remaja dan Solusinya. Pustaka Pelajar: Yogyakarta.

Chen, Z. M., Fu, J. F., Shu, Q. (2020). Diagnosis and treatment recommendations for pediatric respiratory infection caused by the 2019 novel coronavirus. World Journal of Pediatrics.

Departemen Pendidikan dan Kebudayaan. (1999). Kamus Besar bahasa Indonesia, Edisi Kedua. Jakarta: Balai Pustaka.

Hamalik, O. (2010). Proses Belajar Mengajar. PT Bumi Aksara: Jakarta.

Hasnun, A. 2006. Pedoman Menulis untuk Siswa SMP dan SMA. Andi: Yogyakarta.

Huang C, Wang Y, Li X. (2020). Clinical features of patients infected with 2019 novel coronavirus in Wuhan, China. Lancet. 395: 497-506.

Keputusan Menteri Perindustrian dan Perdagangan Nomor 115/MPP/Kep/2/1998 tanggal 27 Februari 1998 tentang sembilan bahan pokok (Sembako).

Kurniawan, H. (2017). Upaya Peningkatan Derajat Kesehatan Pada Anak Di Panti Asuhan Melalui Edukasi Perilaku Hidup Bersih Dan Sehat. Jurnal Pengabdian Masyarakat Ipteks, 3(1): 9-16.

Mubarak. (2007). Promosi Kesehatan. Graha Ilmu: Yogyakarta.

Notoatmodjo, S. (2007). Promosi Kesehatan dan Ilmu Perilaku. Rineka Cipta: Jakarta. 
Papalia, D. E., Olds, S. W., Feldman, R. D. (2008). Human Development (Psikologi Perkembangan). Diterjemahkan oleh Anwar, A. K. Anwar. Kencana: Jakarta.

Peraturan Menteri Kesehatan Republik Indonesia Nomor 2269/MENKES/PER/XI/2011 Tentang Pedoman Pembinaan Perilaku Hidup Bersih dan Sehat (PHBS).

Rahmadeni, A. S., Hayat, N., Novia R., Siska, D., \& Yunaspi, D. (2019). Penyuluhan Perilaku Hidup Bersih dan Sehat dan Pembagian Sembako pada Anak di Panti Asuhan Mahabbatul Haq Tanjung Uma Batam. Jurnal Abdimas Saintika, 1(1), 141-144.

Rahmat, J. (1999). Islam Alternatif. Mizan: Bandung.

Razi F., Yulianty V., Amani, S A., Fauzia J H. (2020). Bunga Rampai COVID-19: Buku Kesehatan Mandiri untuk Sahabat. PD Prokami: Depok.

Sanjaya, W. (2010). Strategi Pembelajaran Berorientasi Standar Proses Pendidikan. Prenada Media Group: Jakarta.

Singhal, T. (2020). A Review of Coronavirus Disease-2019 (COVID-19). The Indian Journal of Pediatrics, 87(4): 281-286.

Sudjana, N., \& Rivai, A. (2019). Media Pengajaran. Sinar Baru Algesindo: Bandung.

Syaitut, S. M. (1991). Metodologi Al-Qur'an. CV. Ramadhani: Solo.

Undang-Undang Nomor 4 Tahun 1979 Tentang Kesejahteraan Anak.

Undang-Undang Nomor 23 tahun 2002 Tentang Perlindungan Anak.

WHO. (2020). Coronavirus disease (COVID19) Situation Report-121.

https://www.who.int/docs/defaultsource/coronaviruse/situationreports/20200520-COVID-19-sitrep121.pdf?sfvrsn=c4be2ec6_4 , diakses 20 Mei 2020.

Zimmermann, P., dan Curtis, N. (2020). Coronavirus Infections in Children Including COVID-19. The Pediatric Infectious Disease Journal. 39(5): 355-368. 